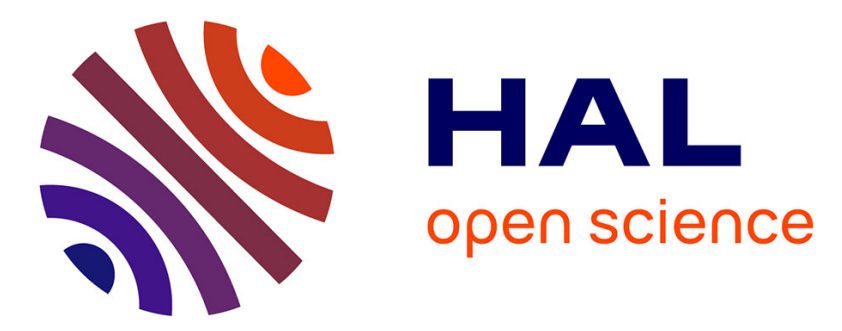

\title{
Social entrepreneurs as change makers: expanding public service networks for social innovation
}

\author{
Anne Vorre Hansen, Lars Fuglsang, Faïz Gallouj, Ada Scupola
}

\section{To cite this version:}

Anne Vorre Hansen, Lars Fuglsang, Faïz Gallouj, Ada Scupola. Social entrepreneurs as change makers: expanding public service networks for social innovation. Public Management Review, inPress, 10.1080/14719037.2021.1916065 . halshs-03230554

\section{HAL Id: halshs-03230554 \\ https://shs.hal.science/halshs-03230554}

Submitted on 20 May 2021

HAL is a multi-disciplinary open access archive for the deposit and dissemination of scientific research documents, whether they are published or not. The documents may come from teaching and research institutions in France or abroad, or from public or private research centers.
L'archive ouverte pluridisciplinaire HAL, est destinée au dépôt et à la diffusion de documents scientifiques de niveau recherche, publiés ou non, émanant des établissements d'enseignement et de recherche français ou étrangers, des laboratoires publics ou privés. 


\title{
Hansen A.V., Fuglsang L., Gallouj F., Scupola A. (2021) \\ Social Entrepreneurs as change makers: expanding public service networks for social innovation
}

\author{
Public Management Review, April, DOI: 10.1080/14719037.2021.1916065
}

\begin{abstract}
Social innovation, in the context of public innovation, has gained increased attention in the literature, and is approached relative to the third sector, to social enterprises, or as practices initiated by the public sector. However, the interplay among these actors in enabling social innovation is still underexplored. Therefore, the article investigates the role of social entrepreneurs from outside the public sector in enabling public sector innovation networks. Since social innovation is inherently relational, four cases demonstrating how social entrepreneurs have pushed the boundaries of public sector services, and hence expanded public innovation networks, are analysed.
\end{abstract}

Keywords: public service innovation; social innovation; social entrepreneurs; innovation networks

\section{Introduction}

In the field of public services, the paradigm shift from traditional public administration to new public management and then to new public governance reflects the rise to prominence of innovation in public services and the networked organization of service production and innovation (Kelly, Mulgan, and Muers 2002; Osborne 2010; Voorberg, Bekkers, and Tummers 2015; Mergel 2018; Crosby, Hart, and Torfing 2017; Torfing, 2019). Researchers have started to pay attention to the emergence of such new types of innovation networks in the public sector, however, the literature is still undeveloped concerning social innovation relative to public services (Sørensen and Torfing 2013). Social innovation and its inherent focus on addressing social needs is often referred to in the literature as a response to 'wicked' problems of today's societies. Therefore, the concern with social innovation becomes relevant to the public sector, both as something realized outside the sector, but also as processes that may be integrated into public sector organizations.

One attempt to conceptualize the emerging focus on social innovation in the context of public services is the construct: Public service innovation networks for social innovation (PSINSI). PSINSIs refer to multi-agent collaborative arrangements that mobilize public and private agents, and citizens in particular, to co-produce social innovations (Desmarchelier, Djellal, and Gallouj 2020a). The main focus of this theoretical framework is the networked aspect of innovation processes and outcomes. However, within social entrepreneurship theory the concept of social innovation is explicitly concerned with how innovation processes should be fruitful for the people engaged in them by transforming relations and by giving access to resources and power, also in the future (Teasdale et al. 2020; Zeyen and Beckmann 2019). Thus, as PSINSIs are more concerned with the network and the outcomes, the particular role of the individual social entrepreneur in public sector innovation processes for social innovation and the underlying perceptions of innovation are still underexplored. 
The research question guiding this analysis is: How do social entrepreneurs external to the public sector spur and add to to public sector innovation networks for social innovation, and with which innovation regime may they be associated?

To answer the research question, a holistic multiple case study of the role of social entrepreneurs in creating public sector innovation networks for social innovation was conducted. The analysis focuses on how the individual social entrepreneur contributes to collective processes of public service innovation and, herein, the expansion of innovation networks targeting social and public challenges. As such, social entrepreneurs appear critical to the sense-making process of such networks, particularly for scaling up, or scaling out, innovations (Moulaert and MacCallum 2019). Hence, the article addresses a gap in the literature on public service innovation networks by conceptualizing the role of the social entrepreneur in expanding public innovation networks for social innovation, while also creating a foundation for further research.

The article is structured as follows: firstly, it provides an overview of the transition from public service innovation networks to PSINSIs, and the implications regarding innovation regimes. Subsequently, current understandings of the concept of social innovation and the role of the social entrepreneur are presented. Following this, the research methodology and the analytical findings are described. Finally, the main findings are discussed and future research avenues are outlined in the concluding remarks.

\section{Towards PSINSIs}

Innovation studies have gradually shifted their analytical focus from visible to invisible innovation, and from the individual entrepreneur to the network via the organization (Martin 2015; Djellal and Gallouj 2018). According to economic theory, an innovation network is a system of relationships among agents whose purpose is innovation. The agents in question do not all have to belong to the same organization, and the relations that link them can take different forms (cooperation, collaboration, co-production, co-innovation, co-design), the definitions of which are the subject of an extensive literature (Keast, Brown, and Mandell 2007; Voorberg, Bekkers, and Tummers 2015; Sørensen and Torfing 2013; Agger and Hedensted 2017; Pestoff, Osborne, and Brandsen 2006).

Desmarchelier, Djellal, and Gallouj (2020a) propose a simple typology of these forms of innovation networks based on the following criteria: 1) the main sector in which the network is deployed, 2) the types of agents involved, 3) the role of the public agent, and 4) the main form of the innovation pursued. On this basis, they observe a tertiarization or servitization of the notion of the innovation network. This process describes a shift in the analytical focus from traditional innovation networks (focused on technological innovation in the manufacturing industry) whose archetype is the triple helix model (Etzkovitz and Leydesdorff 2000), to market service innovation networks (focused on market services and service innovation), and then to public service innovation networks (focused on innovation in all its forms in the field of public services). In innovation networks of any kind, public administration, when present, can play two roles: an operational role of active collaboration in the production and implementation of innovation (co-production), and a role of supporter or facilitator (meta-governance) of innovation. Thus, in traditional innovation networks, public administration is involved mainly through the establishment of regulations and financing systems that are favourable to innovation and networking.

\section{PSINSIS}

Recently, the latest expression of the network lineage (Desmarchelier, Djellal, and Gallouj 
2020a) has been devoted to the emergence of social innovation. The PSINSI concept was introduced to theorize social innovation in public services and how it is implemented through collaborative networks (Desmarchelier, Djellal, and Gallouj 2020a). PSINSIs are multi-agent collaborative arrangements that develop within public services in the sectoral sense of the term, or within public services in the functional sense (i.e. services of general interest). These sorts of collaborative systems for social innovation in public services can be spontaneous or self-organized - in this case, they are the result of the fortuitous convergence of the concerns of agents facing the same problem, often in a given local environment. However, they can also be established in a planned way, initiated by an agent who may belong to the public or private sphere (citizen or organization). Hence, in PSINSIs, the meta-governance role is not excluded; rather, what is most important is the fact that public administration, when involved, participates in an innovation that directly concerns its own sphere of activity (the public service itself). Although they are now taken seriously by academic research (especially in the context of the rise of new public governance) and public policy, PSINSIs remain mostly a black box. There is thus a knowledge gap regarding the nature of the (social) innovation at stake, obstacles and drivers, and the concrete modalities of its formation and functioning (Desmarchelier, Djellal, and Gallouj 2020b).

\section{Innovation regimes and PSINSIs}

Following a Schumpeterian analysis (Schumpeter [1912] 1934, 1942), economic theory distinguishes between two innovation regimes: the entrepreneurial regime and the routinized regime (Windrum and Winter 1984). The first is based on the heroic figure of the individual entrepreneur who introduces radical innovations in a discontinuous way. In the second regime, which follows but does not replace the previous one, innovation is exploitative rather than exploratory. It is therefore incremental and takes place on a continuous basis. The entrepreneurial spirit is, in the latter, closer to Kirzner's alert entrepreneur, who drives processes of equilibration rather than spurring disruption (Kirzner 2009).

The literature highlights an entrepreneurial regime and a routinized regime for both social and public innovation. Research on social entrepreneurship is particularly extensive, and is mainly empirical, accounting for innovative initiatives carried out by 'fiery souls' in the field of social and solidarity economy (Mulgan, Tucker, and Sanders 2007). The literature on public or institutional entrepreneurship is in fact essentially devoted to public intrapreneurship (i.e. the way in which individuals within a public organization can autonomously_-similar to entrepreneurship - implement a public service innovation). It thus reflects a form of mixing entrepreneurial and routinized regimes.

PSINSIs are not considered a new regime of innovation and learning, but a modality of innovation organizing that can itself fit into the two traditional regimes. In other words, just as entrepreneurial and routinized regimes can be applied to social and public innovation produced by individual entrepreneurs or incumbent firms or organizations, so can they be applied to social innovation produced within networks. It is thus possible to highlight PSINSIs that are set up under an entrepreneurial regime and others that are established under a routinized regime. Entrepreneurial PSINSIs can be initiated by an individual private agent, or they can emerge through the convergence of the concerns of several individual entrepreneurs. They are often a response to state failure. It should be noted that, while entrepreneurial PSINSIs are based on the heroic figure of the individual entrepreneur (or several individual entrepreneurs), the constitution of the entrepreneurial PSINSI usually implies the inclusion in the network of a certain number of public or private organizations. Routinized PSINSIs, for their part, are based on collaboration among existing third-sector organizations (associations, foundations, etc.) and/or public service organizations 
(administrations at different levels). Entrepreneurial PSINSIs are intended to evolve towards a routinized regime, with individual nodes of the network becoming organizations (e.g. when the individual social entrepreneur creates an association or a social and solidarity economy enterprise). In the following section, the 'social' aspect of social innovation and social entrepreneurship are further explored.

\section{The (re-)emergence of social innovation}

Since its emergence in the early 19th century, the term social innovation has been a highly contested concept. Adding 'social' to innovation became a synonym for socialism, which in the beginning (at least to conservatives) was still understood in a negative sense-much like the term innovation, which referred to revolutionary action and upheaval (Godin 2015). Later, however, social innovation was related with cooperative forms of social reform more broadly, and by the end of the century, it was associated with new social practices or social change. The change perspective was part of the way that innovation became an inherently positive term for progress and social development in the 20th century. This was pushed forward by Schumpeter's theories, and by the middle of the century, innovation was mainly associated with technological development and entrepreneurship — an understanding that also came to dominate Western world policy (Moulaert and MacCallum 2019).

Nevertheless, alongside the focus on radical change and emancipation in the 1960s, a renewed focus on transforming society added to these prevailing streams of thought. Moulaert and MacCallum (2019) identify 'waves' of international social mobilization: a radical emancipation wave based in social theories pursuing equity and emancipation; a wave based on, for example, neighbourhood and community development as responses to industrial restructuring; and a social and solidarity economy wave as an answer to the 2008 global financial crisis (Moulaert and McCallum 2019). These historical trajectories of, on the one hand, mainstream economic and entrepreneurship theory and practice and, on the other hand, social movements and theories are still mirrored in the differing perceptions and usages of the concept of social innovation today.

\section{A practical and a critical take on social innovation}

This pattern has become evident in the literature through two main streams of thought that are described in different ways: as a strong or weak tradition (Ayob, Teasdale, and Fagan 2016), as a technocratic school or democratic school (Montgomery 2016), or as a 'practical' stream and 'critical' stream, respectively (Moulaert and MacCallum 2019). According to Moulaert and MacCallum (2019), the streams primarily differ in regards to how the transformative role of social innovation is presented and, as a consequence, how social innovation is positioned in the current political-economic order. The practical (weak, technocratic) stream is rooted in the mentioned entrepreneurship and business theories and aims at finding new and better solutions to address social needs. It rests on a market ideology that sees social problems as something that prevent individuals participating in the market economy, and hence focuses on 'what works' - with diffusion of knowledge and scaling up as success parameters. The perspective implies that social innovation is something that can be managed, and this understanding has been highly influential in the approach to social innovation used in the private, public, and third sector. The presented PSINSI framework is positioned herein. Meanwhile, the critical (strong, democratic) stream is rooted in the emancipatory tradition, which sees social problems, and solutions to them, as inherently linked to socio-economic structures and institutions. Thus, social innovation is not solely about problem solving, but more far-reaching, focusing on spurring counter-hegemonic approaches of development 
based on solidarity; here, success parameters relate to scaling out - that is, the transformative potential of wider scales of social mobilization (Moulaert and McCallum 2019). This perspective implies a concern with social innovation as a driver for reconfiguring democratic governance.

Due to the trans-disciplinary nature of social innovation theorizing, the 'practical' and the 'critical' streams are to be seen as a spectrum within which nuances and varied discussions and development of social innovation thinking is taking place. This is especially true since there are commonalities between the two ends of the spectrum, illustrated by a shared understanding of the following key characteristics of social innovation: social innovation addresses social problems and/or human needs, and it is as much about processes as outcomes. This is reflected in the widely applied but narrow definition of social innovation as being social in both means and ends (Gallouj et al. 2018; Mulgan, Tucker, and Sanders 2007). However, a more encompassing definition is the one presented by the EU project TEPSIE, which defines social innovation as: 'New approaches to addressing social needs. They are social in their means and in their ends. They engage and mobilize the beneficiaries and help to transform social relations by improving beneficiaries' access to power and resources' (TEPSIE 2015, 9). In this definition, the main focus is on outcomes and the empowerment of the people concerned by supporting relational changes. As such, social innovation is an emancipatory process leading to social transformation, but it might also be specifically concerned with developing new approaches to support such change.

\section{The social entrepreneur as individual or collective actor}

The approach to social innovation also influences how the social entrepreneur is perceived. Much literature based in the practical stream of thought has focused on the individual entrepreneur as a driver of innovation, and often the social entrepreneur is referred to as a sort of 'heroic' actor who enables social change through creativity (Montgomery, Dacin, and Dacin 2012). A focus of this literature has been the extent to which the social entrepreneur resembles entrepreneurs in general, and the argument is that their traits are similar. What is added, besides the entrepreneurial mindset and the capacity to balance a dual purpose, is that the social entrepreneur should be able to creatively and innovatively combine existing resources or create new ones that are oriented towards a social goal (Lortie and Cox 2018). Literature based in the critical stream of thought focuses more on the interplay between multi-level governance and discourse, and collective actors and communities (Moulaert and McCallum 2019). This collective perspective is increasingly emerging based on the argument that social entrepreneurship, as a broad domain, is inherently collective-oriented and considered to rely on collaboration and alliances. Hence, collaborative action, among similar or diverse actors, is seen as paramount for solving wider societal challenges (Montgomery, Dacin, and Dacin 2012).

In sum, the theoretical framework applied in the analysis consists of the following three conceptual understandings: PSINSIs as theoretical lenses to understand cross-sectorial collaboration targeting social challenges, social innovation as process and outcome, and social entrepreneurs as both individual and collective actors. As such, the framework opens a broader and more nuanced analysis of the interplay between social entrepreneurs, existing networks, and collective action.

Figure 1 to be inserted here

\section{Methodology}

To empirically explore how social entrepreneurs external to the public sector spur and add to 
public sector innovation networks for social innovation in different contexts, the analysis is based on a holistic multiple case study (Yin 2014). It is holistic in the sense that there is one unit of analysis: the role of social entrepreneurs in expanding public service innovation networks for social innovation; it is a multiple case study because four cases are considered. To get as nuanced a picture as possible, case selection criteria were focused around the following: actors from the private sector (exemplified by Cases 1 and 4), an actor from the third sector (Case 2), and an actor from the public sector (Case 3).

Finally, the founders (and now the established organizations) of Cycling Without Age, Mind Your Own Business, E-Bro, and Citybee were chosen as cases. All four cases are from Denmark, and are in the Danish context often identified both within and outside of academia as role models of social innovation initiatives that address social challenges (Fuglsang, Hansen, and Scupola 2019). The Scandinavian welfare state is argued to facilitate the relationship between civil society and the state to stimulate solidarity among groups of citizens (Hulgård and Andersen 2019). Along these lines, the case organizations depend on collaboration with the public sector and rely on cross-sector networks. Therefore, they are relevant to understanding the preceding conditions for social innovation to occur and become sustainable, herein identifying the main actors and exposing the institutional factors (broadly understood). As such, the cases are paradigmatic since they set the standards for future likely cases (Flyvbjerg 2006).

\section{Cases and data}

\section{Case 1: Cycling Without Age (CWA)}

CWA is mainly perceived by its founders and employees as a movement grounded in legal and organizational units in order to operate, collaborate, apply for funding, and hire employees. The movement started in 2012 but was not formally and legally established until 2015. The main idea is that elderly people living in care centres or provided home care are offered bike rides in a trishaw. The trip involves what is referred to as the three Ps: pilots, passengers, and personnel. The pilot (driver) is either a volunteer or an employee from the care centre or home care agency, the passenger is the elderly person, and the personnel are the employees and administrators at the care centre or home care agency. The main objective of CWA is presented as giving the elderly the right to feel the wind in their hair by ensuring mobility and active participation in society. Besides mobilizing civil society actors and private companies as donors, CWA is highly dependent on public actors to gain access to the target group (the elderly); this is because, in the Danish context, elderly care is a welfare service.

\section{Case 2: Mind Your Own Business (MYOB)}

Since 2010, MYOB has been organizing and facilitating development projects for adolescent boys, between the ages of 13 and 19, from marginalized housing areas. The program is centred around entrepreneurship. In cooperation with voluntary venture pilots from civil society and business partners, the young boys are given the opportunity to start their own micro-enterprise. An established team of approximately 10-12 boys, eight or nine venture pilots, a business partner, and contacts from the engaged youth club or the non-profit housing department runs each micro-enterprise. Thus, almost 200 people participate in the program each year. The philosophy behind MYOB is that the program develops the professional and social competencies of the young boys, thereby enabling a stronger association with the 
educational system and the job market. The organization itself maintains 12 employees who mainly work as project managers, project coordinators, or project workers. MYOB collaborates with the municipal youth clubs and social workers from the non-profit housing association to identify and recruit youngsters for the program.

\section{Case 3: E-bro}

E-bro has developed an IT solution called 'JobIntra', which addresses the flexi-job scheme, an initiative within the Danish unemployment scheme. The flexi-job scheme targets people in any profession with permanently and significantly reduced ability to work. In many ways, a flexi-job is normal employment, where tasks and working hours are adapted to what the individual flexi-job employee can handle. JobIntra has made the process of finding a flexi-job more efficient for job centres. The basic model is a 'no cure-no pay' model. Hence, E-bro develops the system, which they sell to job centres; there are establishment costs, and a unit price for each citizen entered into the system is charged, which applies for six months. At the end of the six months, if the citizen does not get a job, then E-bro does not get the money. The goals of E-bro are to: 1) improve society for all citizens; 2) avoid capitalism; and 3) use ideology and politics to contribute to making the world a better place for all parties. Since Ebro targets a key public service, the organization is inherently linked to and dependent on public sector collaboration.

\section{Case 4: Citybee}

The association Citybee was established in 2009 and founded on an urge to find a model of production that would contribute to a richer environment and inclusive communities. Finding a new model in the face of climate change and social transformation was seen as urgent-and honeybees and pollination seemed to offer both a model and a metaphor. Citybee rents beehives to public, private, and social organizations in Copenhagen. The beehives are placed around the city, on the rooftop of or near the organization's building, and Citybee is in charge of processing and selling the honey produced by the rented beehives. Citybee also conducts beekeeping and honey production courses and organizes workshops and events. There are five employees of different backgrounds at Citybee, and several volunteers help out with practical work (the number of volunteers changes from 2 to 15 during the bee season). The association describes itself as working to enrich the environment and believing that everyone has something to contribute, whatever their background. As a honey producer, Citybee is mainly dependent on collaborating with organizations that wish to rent beehives, but due to the ideology of mobilizing people on the border of the job market, they also rely on the municipal job centres for recruiting.

Table 1 gives an overview of the data collected in each case. In accordance with the research question, the most central part of data is the four in-depth interviews with the founders of each organization. These interviews were conducted first, and acted as a backdrop for the subsequent interviews, which refined and added new perspectives to the knowledge obtained.

Table 1 to be inserted here

\section{Analytical strategy}

The data were transcribed and analysed by focusing on the experiences and perceptions of the actors involved. To support transparency, the conceptual distinction between emic and etic perspectives was applied as a foundation for the analytical findings (Harris 1976). Emic 
refers to the concepts used by informants, whereas etic refers to the analytical concepts used by the researcher (Harris 1976; Silverman 2006). Consequently, the data were subjected to a thematic analysis consisting of three main steps (Silverman 2011). Firstly, emic themes were identified across data sets; these themes addressed what was at stake for the interviewees and in key documents, and how these ideas were articulated. The themes were grouped under 12 first-order categories summing up the substance of the data. The second step in the analysis involved the etic perspective of recognizing the links and patterns between these categories and establishing second-order categories based on the joint analysis of the researchers. Lastly, the second-order categories were organized into three overall analytical themes. The conceptual construct of first- and second-order categories supports analytical transparency, as visualized in Figure 2 below.

Figure 2 to be inserted here

\section{Analysis}

In this section, the empirical findings based on the following main themes identified in the data are presented: 1) the ethos of the social entrepreneur, 2) network enabling and network enabler, and 3) social entrepreneurs as triggering public sector innovation.

\section{The ethos of the social entrepreneur}

The foundational stories of the four cases are all characterized by a degree of chance and personal commitment to a cause. The founders of CWA and Citybee describe how they, more or less by chance, got an idea and were urged to action when they were cycling home and saw a lonely elderly person sitting on a bench, or discovered a barely concealed beehive. Diving deeper into these narratives, it is also evident that ideas and action do not happen out of the blue, and that both founders were already focused on making change as part of either their personal life or their work life. In the cases of MYOB and E-bro, the trigger for doing something differently evolved over time through their experience in a certain work field. Both founders were already working closely with the actors and in the context for which they later came to develop answers. The CEO of MYOB had spent years working with marginalized families and children as part of a large NGO. As such, she witnessed first-hand that young boys, in particular, fell through the security net of the welfare state. She notes:

\footnotetext{
there were times where I thought to myself, 'we could have prevented this', I mean, if it is a family with four boys and three of them were already placed in care. . . . So, to me it became about prevention instead of being part of a system just waiting to sanction. That was my motivation.
}

The founder of E-bro, by working at a job centre in a municipality, had seen the importance of disabled citizens getting and being in a job. He experienced the significance for all people to contribute to society and how they got 'stuck' if they had nothing to do. To him, this was the main motivation for helping a specific citizen group to find employment.

These motivational triggers - whether a spontaneous idea or evolving insight into a specific domain-led all four founders to take action. However, even though they, in retrospect, can be perceived as social entrepreneurs, and as such they resemble the heroic entrepreneurial figure, only the founder of CWA was an entrepreneur and idea generator beforehand. Thus, a key characteristic of the social entrepreneur is the 'necessity to act', rather than an urge to become an entrepreneur as such. All four founders identified a problem in society and, instead of solely pinpointing the challenge, they reacted to make a change. 
These reactions and their ability to take action is deeply linked with their individual skills and competencies. In the case of CWA, the founder was an experienced event planner and business person. For MYOB, the founder had deep knowledge about the target group gained through experience and education as a social worker. Citybee's founder was a social enterprise manager concerned with kinship and how to create meaningful communities. Lastly, the founder of E-bro was working in public administration and was familiar with the regulations and the people concerned.

Interestingly, the clear narrative of making a change has, in all four cases, evolved. What started out as an urge to react based on a perceived indignation is today discursively constructed as a systems critique. Hence, the objectives of the organizations are two-fold: to create value at a subjective level for the people involved and targeted through the different initiatives, and to create societal value by changing practices and perspectives at a systemic level. To illustrate subjective value creation, a manager at CWA stated: 'We see ourselves as a tool to make people who normally do not have a voice in society heard. And this is based on the intimacy created by cycling - in this manner, they are "talked" back into society'. Furthermore, the focus on making change at a societal level is mirrored in organization's mantra: 'Ride by ride, we change the world'.

Citybee's founder more explicitly emphasizes the objective of changing prevailing production systems using the metaphor of bees and honey. The case adds to environmental enrichment (providing bees and flowers in Copenhagen's urban environment) while also developing new forms of inclusive production and co-production, which is founded on a systemic critique of existing practices and terminologies. The founder stresses that honey is not:

seen as a product in itself, but as an invitation to plant a flower, to see the environment in a new way, to connect the homeless person or the refugee from Syria with the buttered toast and honey that you might enjoy in your kitchen with your children.

In sum, the ethos of these social entrepreneurs is that of a change-maker or someone who takes action based on wanting to create change at both an individual and a societal level. This is, on the one hand, realized through personal skills and competencies, but on the other hand, involves the surrounding network and contextual factors that play a key role.

\section{Network enabling and network enabler}

It is one thing to be part of a relevant network, and another thing to bring that network into play. Across the four cases, using existing platforms and networks has been a prerequisite for establishing and making the organizations sustainable. For example, MYOB's founder developed the program from a position in the Danish Refugee Council. As such, the NGO acted as a platform for pilot testing the idea and for developing the structure of the initiative. Thus, MYOB was not established as an independent organization before the time was ripe for the founder, and the council, to separate the program as an initiative in its own right. Likewise, CWA has, from the beginning, strategically used social media as a platform for storytelling, creating events, and for reaching out to volunteers and stakeholders. Their founder also widely drew upon his existing personal network in both the private and the public sectors. The stories that flourished on social media platforms created a legitimate space for contacting key actors in Copenhagen. One of these municipal managers embraced the idea and later became co-founder of the organization.

Besides these two concrete examples of using existing platforms - be they professional, personal, or digital - the key aspect of releasing resources is observed across all cases. The practice of storytelling and the creation of messaging that actors could envision 
and react to were crucial in mobilizing and expanding networks. The founders cited storytelling as a strategic tool applied at both intersubjective and strategic levels. For example, the founders of CWA and Citybee have done TED Talks and, for CWA, a public manager stated that the decision to implement the service was made at a political level because politicians bought in to the story. The founder of E-bro also reflected on how the established collaboration was based on the story of a 'good cause':

We have created an interaction platform that makes it possible to exchange information. The problem today is that there are many people around the individual who do not work together. It can be the job centre, a physiotherapist, and, for example, an employer, each of whom works for 'the good cause'. Instead of acting individually, it is now possible to work together with the vulnerable towards common goals.

Another factor that the founders referred to is: 'right' timing. Timing involves the current meta-stories and condition of society. For example, in the Danish context, there was and is awareness of loneliness among older adults and the challenges faced by minority groups in entering the job market, which MYOB, Citybee, and E-bro tap into. At a corporate level, MYOB and Citybee both address Corporate Social Responsibility (CSR) strategies of large companies (in Denmark, this is a legal requirement if an organization has more than 250 employees). Thus, the companies that are part of the MYOB program or host beehives can integrate and document this as a CSR initiative. Another example of right timing, but from within the public sector, is seen in the case of CWA, where the contemporary state of affairs within elderly care made room for the initiative, as noted by a public manager:

I think the CWA was introduced at a time where the pressure was so high within elderly care that is was possible to realize. If it had been years before, when there was more money, it probably would already have been part of the service offering.

Besides timing, an interesting aspect of network enabling is the ability to find and mobilize the intrapreneurs of collaborating organizations in order to succeed. As mentioned, CWA's founder was directed to a public manager, strategically positioned in elderly care, who was perceived by someone in his network as open-minded and supportive of change. Moreover, to recruit care centres to the programme, public administration managers know which centre managers are the most proactive and receptive to new ideas - and this has played a key role in rolling out the program. The founder of MYOB adds to this by stressing that organizations, first and foremost, consist of people, which is why it is important to identify which actors are willing to take a risk and establish relationships:

I have had rejections from the former integration ministry who didn't believe in it because they didn't believe the target group was capable of this. Therefore, I have been very happy that some funds have helped build this up, that they dared and were willing to take some risks in their donations, saying 'this sounds interesting, but it also sounds difficult'. It has required many cups of coffee since this is built on networks and relations.

As the above illustrates, mobilizing existing networks and platforms is the first step in expanding and creating new networks. As such, network enabling is a dynamic process influenced by timing and pointed in the direction of intrapreneurs. 


\section{Social entrepreneurs as triggering public sector innovation}

The four cases are examples of social innovation in the sense that the social entrepreneurs succeeded in releasing existing resources and, through collective mobilizing, created new processes and offerings that target societal challenges. However, they are not examples of structured and deliberate innovation processes, since the founders did not set out to do innovation; even though they were motivated by and acted to create change, they did not think in terms of innovating the public sector. Still, all four cases are somehow dependent on and engaged in collaboration with the public sector. The implications for the public sector and the case initiatives are intertwined: 1) the organizations needed to become a legal unit with which the public sector could collaborate, which led to organizational maturity and establishment; and 2) the urge to engage in collaboration from a public sector perspective has led to public sector innovation due to how the cases challenge existing norms and practices.

As CWA demonstrates, it became clear to the founders that, at some point, the time was ripe to move from being 'a movement for a good purpose belonging to the people' to a foundation that had the ability to ensure stable funding: 'to become someone to be addressed legally'. An informant from MYOB adds to this perspective, noting that being pushed to find new solutions within the frame of existing logics developed the organization itself: 'We almost never fall into existing boxes, hence, we need to ensure specially designed solutionswhich has become a competency of ours in itself'.

There is a shared understanding across cases that these organizations push the boundaries of what is possible to achieve in cross-sectorial collaboration. In the case of CWA, the initiative relies on mobilizing public sector resources since the actors from elderly care play a key role. As such, CWA has supported new forms of organizing, both internally at the care centres and externally through the involvement of volunteers and the immediate environment: 'It [CWA] somehow forces the public sector and civil society to enter each other's domains and to explore and understand what kind of logics are at stake, respectively', a public manager states.

In MYOB, the public actors are not part of the program itself, but they are important practical enablers who provide access to venues and the boys through the youth clubbesides offering professional support, should the boys need it. This background facilitating role has caused some discussion and adaptation among the public sector actors. As the founder of MYOB stresses:

What is important is that the municipalities accept that they are stepping into something new, a change model, where they need to be involved, but where they should not control or manage. They have to accept this as it is and not perceive us as consultants doing everything - but instead see us as an organization gathering some actors to leverage this program so their municipality and housing area are taken to another place.

At a systemic level, in the cases of E-bro and MYOB, there are also traces of disruption. MYOB pushes the formal collaborators to change their way of operating and to invent new modes that are aligned with the needs of the micro-enterprises. As a collaborator from the non-profit housing sector described: 'We succeeded in implementing the whole economic structure for participating in the program, so if new actors want to engage, there is actually already funds in the municipality to apply for'.

MYOB has deliberately approached trade organizations and headquarters to make it easier for, among other things, the local bank offices to find solutions - which they have done. In this manner, they succeeded in obtaining specially designed solutions that addressed the formal institutions' need to be flexible and to support the program. When accounting for 
the collaboration with E-Bro, a public manager reflects: 'E-Bro's IT solution turned the process upside down: now it is the subcontractor who identifies relevant citizens and facilitates the match-making'. In this manner, E-bro as an external actor has succeeded in changing not only existing processes, but also the mindsets of public managers relative to who is the responsible for what.

In a conversation about hosting beehives from Citybee and enabling employees to follow the process of honey production, a private sector manager stressed how the daily dialogue among storekeepers changed from everyday discussions to talks about the environment and sustainability. These more substantial changes are what Citybee aims for. As the founder reflects:

It is easier to act your way into new ways of thinking than to think your way into new ways of acting. The only thing that we can say for certain about how life will be in 20 or 30 years from now for our children and grandchildren is that it is not going to be anything like what we have now. But we can create structures now that will allow new systems to emerge.

To summarize, all four cases are examples of social innovation emerging in the interplay between the public sector and the third sector and/or civil society. Yet, these cases are not initiated or 'owned' by the public sector itself, but are dependent on and situated within a network of cross-sector collaboration. As such, they are examples of bottom-up social innovation and not specific public sector innovation processes per se.

\section{Discussion}

In the literature on PSINSIs, the focus is on social innovations targeting complex or 'wicked' social problems. The public sector itself might play different roles (if any), from initiator to facilitator, but either way, the sector is involved in innovation that directly relates to its own sphere of activities (Desmarchelier, Djellal, and Gallouj 2020a). The four cases analysed here can be understood in terms of PSINSIs; they represent cases of social innovation initiatives mainly triggered from outside the public sector, that are still dependent on establishing collaboration and networks that associate to different degrees with the public sector. In the following the analytical insights will discussed relative to the theoretical framework applied.

\section{Dynamic aspects of social innovation}

As mentioned earlier, the concept of social innovation stems from two historical trajectories: mainstream economic theory and social movement theory. Like most conceptualizations of social innovation in public administration, PSINSI theorizing falls within the former. That is, social innovation is seen as a solution and as an outcome. On the contrary, the latter stream of thought emphasizes the transformative potential of social innovation based on collective processes involving the people concerned (Montgomery, Dacin, and Dacin 2012).

The cases at hand expose dynamic aspects of processes leading to social innovation within the public sector. They are not structured and deliberate innovation processes with the main aim of delivering solutions to identified challenges - and hence to 'fix' a public sector problem (Moulaert and MacCallum 2019). Rather, they are initiatives triggered by a personal indignation with existing practices and structures; they not only focus on solving a challenge at a subjective level, but also seek to change the system itself. In this manner, the cases are based on dynamics of change; they demonstrate that, if you can make a change at the individual level, you also set the groundwork for making a change that can lead to societal or 
institutional changes at a collective level. The implication relative to innovation is that of a processual perspective on innovation; it is not understood as a specific method or model for innovation, but merely as an approach to explore and develop the overall objective of social change (Barinaga 2012). Hence, the four cases resemble social innovation, in line with both the practical and the critical stream of thought that emphasizes collective action and change.

These social innovation aspects are further mirrored in the cases, as they have not only succeeded in upscaling, but have also, to different degrees, succeeded in scaling out (Moulaert and MacCallum 2019). Regarding upscaling, especially MYOB, E-bro, and CWA have managed to spread across Danish municipalities. Moreover, the organizations have strategically applied an internationalization strategy: CWA is represented in 27 countries, Ebro has a unit in Ukraine, and MYOB is establishing a unit in Greenland. Citybee is mainly positioned in the capital area of Denmark, but regarding scaling out, they have mobilized a wide range of partnerships across sectors to reach a large number of people through the sale of their honey products in a Danish supermarket chain. MYOB, CWA, and E-bro can also be seen in light of scaling out insofar as they seek to create and spur, through communication and in practice, counter-hegemonic approaches to public service offerings based on mobilizing citizens and private and public actors in collective action.

As such, the organizations participate in creating new structures, understandings, and practices because they relate to the outcome of the initiatives as well as to the process of establishing the organizations and becoming able to continuously offer their services, products, or programmes. Relative to the increased focus on cross-sector collaboration for public innovation (Sancino, Rees, and Schindele 2018), the initiatives are exactly what the critical perspective on social innovation implies: social innovation processes are drivers for reconfiguring democratic governance (Moulaert and MacCallum 2019).

\section{Entrepreneurial roles and innovation regimes}

Returning to the role of the social entrepreneur, the cases furthermore refine the understandings of different innovation regimes and how they might be enacted in a public sector context. Seen through the lens of innovation regimes theory (Windrum and Winter 1984), the ethos of the social entrepreneur in each case transcends the entrepreneurial and the routinized regime. All founders mirror both the heroic entrepreneurial figure (Mulgan, Tucker, and Sanders 2007) and the alert entrepreneur (Kirzner 2009) insofar as they not only identify challenges, but also drive processes forward and act on behalf of people who lack a (big) voice in society. However, the ability and the platform for taking action depend on possessing and expanding existing networks; they are furthermore conditioned by current tendencies and changing mindsets in society. Hence, despite the individual 'fiery soul' being a key (f)actor in all cases, the initiatives have incrementally evolved in close collaboration with a network of actors from across sectors.

The presented cases therefore reveal new aspects of social innovation that are based in a novel domain where innovation and change occur on the borders of the public sector. All cases are concerned with systemic change: through physical movement (a bike ride), by getting someone (figuratively speaking) from Point A to Point B (preparing them for the labour market), and using IT innovation or new philosophies of production to effect change. As discussed, the focus on systemic change challenges existing presumptions of social innovation in the public sector, which is why a deeper understanding of social entrepreneurship logics and the social entrepreneurial ethos might create space for actors outside the sector to contribute to institutional and public sector change through interactive and collective processes.

To promote forms of social innovation that are not necessarily structured as public innovation, the public sector itself needs to adhere to a more entrepreneurial mindset of 
innovation, especially since the cases also show that the more the organization is dependent on collaborating with the public sector, the less transformational it can be. CWA is, for example, considered by the public managers as merely an add-on to existing public service offerings. Therefore, to embrace these types of innovation processes and to emphasize the dynamic aspects of social innovation, a refined framework of PSINSIs is proposed: social innovation networks are to be seen as enablers of public innovation and not solely as outcomes of public sector innovation networks.

\section{Conclusion}

The paper explores the following research question: How do social entrepreneurs external to the public sector spur and add to public sector innovation networks for social innovation, and with which innovation regime may they be associated? Through a holistic multiple case study of four cases from Denmark it became clear how three key factors help us understand the dynamics between social innovation networks and public sector innovation. These three factors are: (1) the ethos of the social entrepreneur external to the public sector; (2) how they enable existing and new networks; and (3) how a social entrepreneurial mindset, encompassing a practical and a critical approach to social innovation, triggers public sector innovation.

Moreover, it is concluded that, by taking action at an individual level, social entrepreneurs create collective action through relationship building and community mobilizing. Hence, in regards to innovation regimes, the entrepreneurial regime shall, in this context, be seen as an interactive collective process that, over time, leads to incremental innovation - that is, a routinized regime - and to more radical innovation.

In sum, this study adds to the PSINSIs literature a dynamic understanding of the processes that lead to social innovation. The contribution to the social innovation literature is a dual focus on the individual social entrepreneur and the collective actions they stimulate. The implication is that individual and collective processes, and that entrepreneurial and routinized innovation regimes, do not solely represent poles on a spectrum, but might be understood and analysed as intertwined in time while also being interdependent. The contribution to practice, especially public sector managers and policy makers, is an increased understanding of the role of social entrepreneurs external to the public sector in developing public services. This is applicable in ensuring adaptiveness from within the sector in building networks and infrastructure that supports such forms of collaboration and entrepreneurial activities.

The study at hand is limited to a Danish context, based in a Scandinavian welfare model. Also, the interview data are mainly focused on the social entrepreneurs themselves, and less on informants representing the managerial and policy-level of the public sector. Hence, to better understand social innovation in the public sector, future research could further explore how social innovation initiatives and networks stemming from outside the sector create new solutions and structures that might spur further innovation, and in what way these interplay with existing public practices and logics. Consequently, the unit of analysis shifts from public sector innovation networks for social innovation to social innovation networks as public innovation.

Funding statement: This project has received funding from the European Union's Horizon 2020 research and innovation programme under grant agreement No 770356. This publication reflects the views only of the authors, and the Agency cannot be held responsible for any use, which may be made of the information contained therein. 
Disclosure statement: No conflicts of interest.

\section{References}

Agger, A., and D. L. Hedensted. 2017. "Collaborative Innovation in the Public Sector: New Perspectives on the Role of Citizens?" Scandinavian Journal of Public Administration 21 (3): $17-37$.

Ayob, N., S. Teasdale, and K. Fagan. 2016. "How Social Innovation 'Came to Be': Tracing the Evolution of a Contested Concept.” Journal of Social Policy 45 (4): 635-653.

Barinaga, E. 2012. "Overcoming Inertia: The Social Question in Social Entrepreneurship.” In Handbook on Organisational Entrepreneurship, edited by D. Hjorth, 242-256. Cheltenham, UK: Edward Elgar.

Crosby, B. C., P. Hart, and J. Torfing. 2017. "Public Value Creation through Collaborative Innovation.” Public Management Review 21 (1): 655-669.

Desmarchelier, B., F. Djellal, and F. Gallouj. 2020a. "Towards a Servitization of Innovation Networks: A Mapping." Public Management Review 22 (9): 1368-1397. doi:10.1080/14719037.2019.1637012

Desmarchelier, B., F. Djellal, and F. Gallouj. 2020b. "Public Service Innovation Networks (PSINs): An Instrument for Collaborative Innovation and Value Co-Creation in Public Service(s)." European Review of Service Economics and Management 2020-2 (10): 133-169.

Djellal, F., and F. Gallouj. 2018. "Fifteen Challenges for Service Innovation Studies." In A Research Agenda for Service Innovation, edited by F. Gallouj and F. Djellal, 1-25. Cheltenham, UK: Edward Elgar.

Etzkovitz, H., and L. Leydesdorff. 2000. "The Dynamics of Innovation from National Systems and 'Mode 2' to a Triple Helix of University-Industry-Government Relations." Research Policy 29: 109-123.

Flyvbjerg, B. 2006. "Five Misunderstandings about Case-Study Research." Qualitative Inquiry 12 (2): 219-245.

Fuglsang, L., A. V. Hansen, and A. Scupola. 2019. "Danish Case-Studies Report: Case Study Report. Case Studies WP6: Denmark." In Empirical Approach to Value Co-Creation in Public Services: Structural Transformations: EU-H2020 Co-VAL, Deliverable 6.1, 197-285. Brussels: European Commission.

Gallouj, F., L. Rubalcaba, M. Toivonen, and P. Windrum. 2018. "Understanding Social Innovation in Services Industries." Industry and Innovation 25 (6): 551-569.

Godin, B. 2015. Innovation Contested: The Idea of Innovation Over the Centuries. New York: Routledge.

Harris, M. 1976. "History and Significance of the EMIC/ETIC Distinction." Annual Review of Anthropology 5: 329-350. 
Hulgård, L., and L. L. Andersen. 2019. "Reconfiguring the Social and Solidarity Economy in a Danish/Nordic Welfare Context." In Theory of Social Enterprise and Pluralism: Social Movements, Solidarity Economy, and the Global South, edited by P. Eynaud, J. Laville, L. dos Santos, S. Banerjee, F. Avelino, and L. Hulgård, New York: Routledge

Keast, R., K. Brown, and M. Mandell. 2007. "Getting the Right Mix: Unpacking Integration Meanings and Strategies.” International Public Management Journal 10 (1): 9-33.

Kelly, G., G. Mulgan, and S. Muers. 2002. Creating Public Value: An Analytical Framework for Public Service Reform. London: Cabinet Office Strategy Unit, United Kingdom Cabinet Office.

Kirzner, I. 2009. "The Alert and Creative Entrepreneur: A Clarification." Small Business Economics 32: 145-152. doi:10.1007/s11187-008-9153-7.

Lortie, J., and K. C. Cox. 2018. "On the Boundaries of Social Entrepreneurship: A Review of Relationships with Related Research Domains." International Entrepreneurship and Management Journal 14 (3): 639-648. doi:10.1007/s11365-018-0514-7.

Martin, B. 2015. "Twenty Challenges for Innovation Studies." Working paper SWPS 201530, SPRU Working Paper Series, University of Sussex Business School

Mergel, I. 2018. "Open Innovation in the Public Sector: Drivers and Barriers for the Adoption of Challenge.gov." Public Management Review 20 (5): 726-745.

Montgomery, A. W., P. A. Dacin, and M. T. Dacin. 2012. "Collective Social Entrepreneurship: Collaboratively Shaping Social Good." Journal of Business Ethics 11 (3): 375-388. doi:10.1007/s10551-012-1501-5.

Montgomery, T. 2016. “Are Social Innovation Paradigms Incommensurable?" Voluntas: International Journal of Voluntary and Nonprofit Organizations 27 (4): 1979-2000.

Moulaert, F., and D. MacCallum. 2019. Advanced Introduction to Social Innovation. Cheltenham, UK: Edward Elgar.

Mulgan, G., S. Tucker, R. Ali, and B. Sanders. 2007. Social Innovation: What Is It, Why It Matters and How It Can Be Accelerated. London: The Young Foundation.

Osborne, S., ed. 2010. The New Public Governance? London: Routledge.

Pestoff, V., S. P. Osborne, and T. Brandsen. 2006. "Patterns of Co-Production in Public Services: Some Concluding Thoughts." Public Management Review 8 (4): 591-595.

Sancino, A., J. Rees, and I. Schindele. 2018. "Cross-Sector Collaboration for Public Value Co-Creation: A Critical Analysis." In From Austerity to Abundance? Creative Approaches to Coordinating the Common Good, edited by Margaret Stout, 59-73. Bingley, UK: Emerald.

Schumpeter, J. A. 1934 (1912). Theorie der wirtschaftlichen Entwicklung, Leipzig: Duncker \& Humblot [The Theory of Economic Development]. Translated by X. Cambridge, MA: Harvard University Press. 
Schumpeter, J. A. 1942. Capitalism, Socialism and Democracy. New York: Harper.

Silverman, D. 2006. Interpreting Qualitative Data: Methods for Analyzing Talk, Text and Interaction. London: SAGE.

Sørensen, E., and J. Torfing. 2013. "Enhancing Social Innovation by Rethinking Collaboration, Leadership and Public Governance." Paper presented at the annual meeting of NESTA Social Frontiers, London, United Kingdom,

Teasdale, S., M. J. Roy, R. Ziegler, S. Mauksch, P. Dey and E. B. Raufflet. 2020. 'Everyone a Changemaker? Exploring the Moral Underpinnings of Social Innovation Discourse Through Real Utopias". Journal of Social Entrepreneurship. Vol. ahead-of-print:1-21.doi: $10.1080 / 19420676.2020 .1738532$

Teasdale, S., and P. Dey. 2019. "Neoliberal Governing through Social Enterprise: Exploring the Neglected Roles of Deviance and Ignorance in Public Value Creation." Public Administration 97 (2): 325-338. doi:10.1111/padm.12588.

TEPSIE. 2015. Doing Social Innovation: A Guide for Practitioners. Brussels: European Commission.

Torfing, J. 2019. "Collaborative Innovation in the Public Sector: The Argument." Public Management Review 21 (1): 1-11.

Voorberg, W., V. Bekkers, and L. Tummers. 2015. "A Systematic Review of Co-Production and Co-Creation: Embarking on the Social Innovation Journey." Public Management Review 17 (9): 1333-1357.

Windrum, P. and S. G. Winter. 1984. "Schumpeterian Competition in Alternative Technological Regimes." Journal of Economic Behavior and Organization 5, 287-320.

Yin, R. K. 2014. Case Study Research, Design and Methods. 5th ed. Los Angeles: SAGE.

Zeyen, A. and M. Beckmann. 2019. "What Is Social Entrepreneurship (Not)?". In Zeyen, A. and Beckmann, M., Social Entrepreneurship and Business Ethics - Understanding the Contribution and Normative Ambivalence of Purpose-driven Venturing. NY and London: Routledge. 
Table 1. Overview of data material

\begin{tabular}{|c|c|c|c|c|}
\hline $\begin{array}{l}\text { Type of } \\
\text { data }\end{array}$ & Case 1: CWA & Case 2: MYOB & Case 3: E-bro & Case 4: Citybee \\
\hline $\begin{array}{l}\text { In-depth } \\
\text { interviews }\end{array}$ & $\begin{array}{l}\text { One interview with } \\
\text { CEO } \\
\text { Two interviews with } \\
\text { managers } \\
\text { Three interviews with } \\
\text { public managers }\end{array}$ & $\begin{array}{l}\text { One interview with } \\
\text { CEO } \\
\text { One interview with } \\
\text { manager } \\
\text { One interview with } \\
\text { third-sector } \\
\text { collaborator }\end{array}$ & $\begin{array}{l}\text { One interview with } \\
\text { CEO } \\
\text { Three interviews } \\
\text { with public managers }\end{array}$ & $\begin{array}{l}\text { One interview with } \\
\text { CEO } \\
\text { One interview with } \\
\text { employee } \\
\text { One group interview } \\
\text { with private } \\
\text { collaborators }\end{array}$ \\
\hline $\begin{array}{l}\text { Document } \\
\text { studies } \\
\text { (in } \\
\text { selection) }\end{array}$ & $\begin{array}{l}\text { External evaluation: } \\
\text { 'Wind in the hair } \\
\text { gives life quality- } \\
\text { and positive numbers } \\
\text { at the bottom line', } \\
\text { AskovFonden and } \\
\text { CWA } \\
\text { Brand Book, CWA }\end{array}$ & $\begin{array}{l}\text { "MYOB's annual } \\
\text { cycle of work", } \\
\text { MYOB } \\
\text { Evaluation Report: } \\
\text { 'Effect and Process } \\
\text { Evaluation of } \\
\text { MYOB 2014- } \\
\text { 2017', Als } \\
\text { Research APS }\end{array}$ & $\begin{array}{l}\text { External evaluation: } \\
\text { 'Evaluation of } \\
\text { reform of early } \\
\text { retirement benefit } \\
\text { and flex job' } \\
\text { (Deloitte 2018) } \\
\text { "Active labour } \\
\text { market policy } \\
\text { measures", The } \\
\text { Danish Agency of } \\
\text { Labour Market and } \\
\text { Recruitment }\end{array}$ & $\begin{array}{l}\text { Internal evaluation: } \\
\text { 'Honey is something } \\
\text { we create together', } \\
\text { City-Bee } \\
\text { Project description: } \\
\text { The House of the } \\
\text { Bees, City-Bee } \\
\text { Video: Pleasure, } \\
\text { Partnerships and } \\
\text { Productivity }\end{array}$ \\
\hline
\end{tabular}




\section{Figure 1. Theoretical framework}

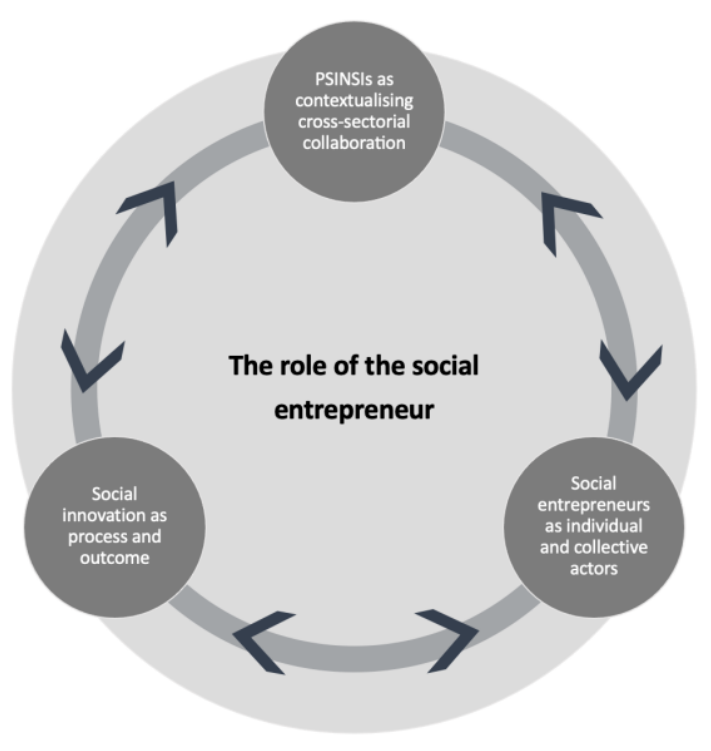

Figure 2. Analytical process

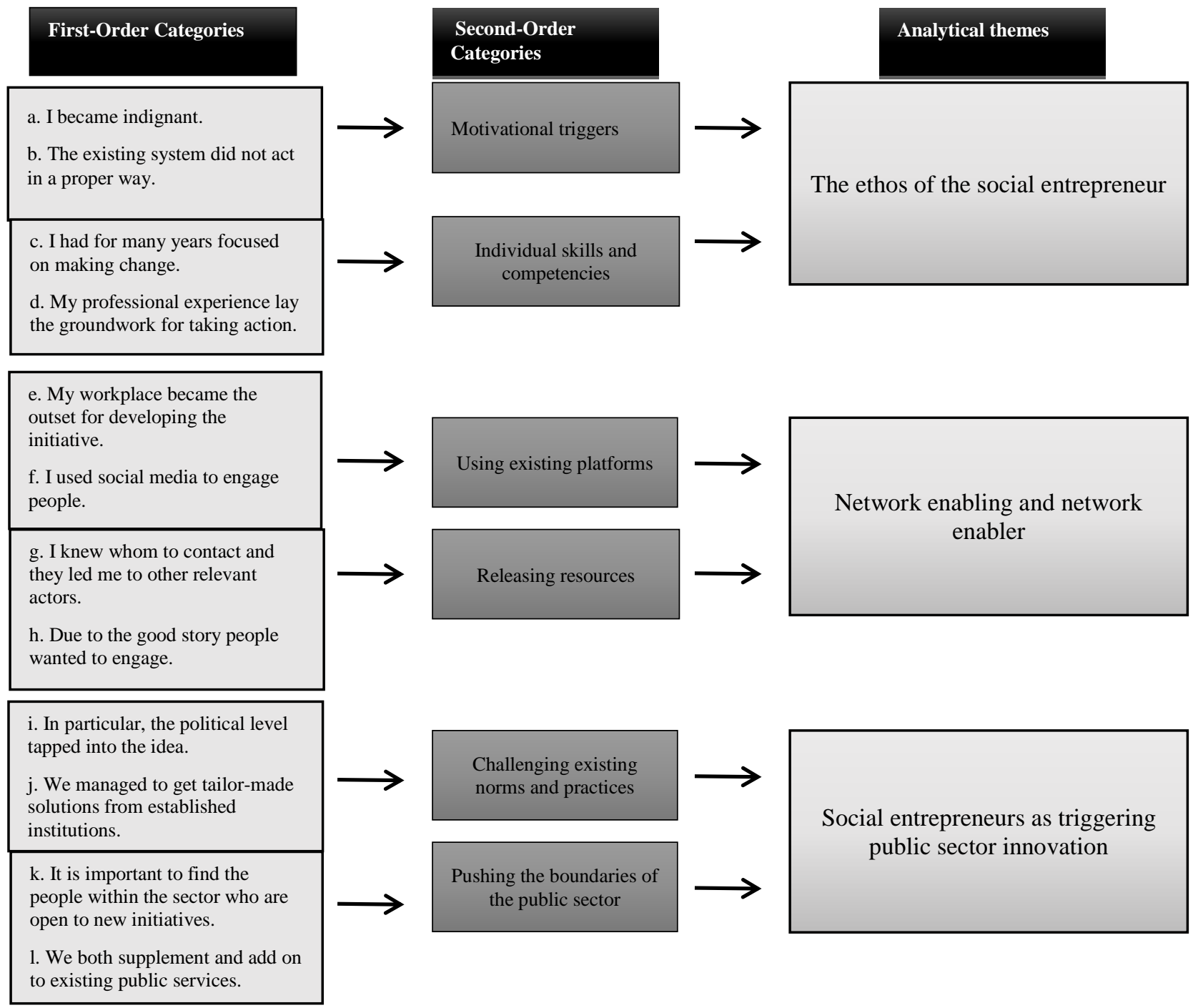

